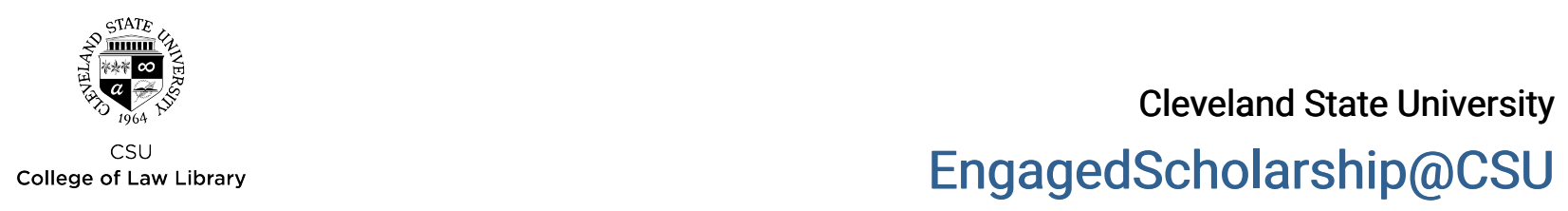

1978

\title{
Egyptian Land Law: An Evaluation
}

\author{
David F. Forte \\ Cleveland State University, d.forte@csuohio.edu
}

Follow this and additional works at: https://engagedscholarship.csuohio.edu/fac_articles

Part of the Comparative and Foreign Law Commons, Land Use Law Commons, Property Law and Real Estate Commons, and the Religion Law Commons

How does access to this work benefit you? Let us know!

\section{Original Citation}

David F. Forte, Egyptian Land Law: An Evaluation, 26 American Journal of Comparative Law 273 (1978)

This Article is brought to you for free and open access by the Faculty Scholarship at EngagedScholarship@CSU. It has been accepted for inclusion in Law Faculty Articles and Essays by an authorized administrator of EngagedScholarship@CSU. For more information, please contact research.services@law.csuohio.edu. 


\section{HEINONLINE}

Citation: 26 Am. J. Comp. L. 273 1977-1978

Content downloaded/printed from

HeinOnline (http://heinonline.org)

Fri Mar 16 14:50:21 2012

-- Your use of this HeinOnline PDF indicates your acceptance of HeinOnline's Terms and Conditions of the license agreement available at http://heinonline.org/HOL/License

-- The search text of this PDF is generated from uncorrected OCR text.

-- To obtain permission to use this article beyond the scope of your HeinOnline license, please use:

https://www.copyright.com/ccc/basicSearch.do?

\&operation $=$ go\&search Type $=0$

\&lastSearch $=$ simple\&all=on\&titleOrStdNo=0002-919X 


\section{EGYPTIAN LAND LAW: AN EVALUATION}

\section{by David F. Forte}

Egypt was not unique when, in 1949 , it undertook to introduce a modern, Western-style Civil Code into a traditional society. Both Islamic and non-Islamic underdeveloped nations have sought to lay a basis for participation in modern economic and commercial activities by adopting a Western civil code. Indeed, even larger states such as the Soviet Union and China (before the rise of Mao Tse-tung) followed the same route.

In all cases, the country adopting the Western code has attempted to infuse it with traditional values or with tenets of a particular ideology. Frequently, the inevitable dichotomy between the basic concepts of the code and the values which have been infused into it produce legal tensions. This has certainly been the case in Egypt. Traditionally, Egypt has had difficulty accommodating a growing population on a limited amount of arable land. Whether Egypt is able to remedy past maldistribution of arable land will have significant social, economic and political consequences. The success of legal reform in Egypt must be judged by the standard which led to the adoption of the Egyptian Civil Code in the first place: has the Code significantly reformed and simplified the law governing the ownership of land?

Based on limited evidence, it seems fair to say that the Code has had but limited success in reforming land law. Indeed in some ways, the introduction of the Code has been counterproductive. This has occurred because Egyptian land law continues to be subject to several countervailing influences.

To begin with, the Code has supplanted significant portions of traditional Islamic land law, as outlined in the Sharïa. Judges are instructed by the Code to apply principles of Muslim law only if code provisions or customs do not provide a basis for deciding a case (Art. 1). The placing of custom before the Shari $a$ is a serious violation of the scheme of authority in traditional Islamic law. Although some of the Code's provisions relating to estates in land were derived from Islamic law, a reading of the Code makes it clear that such provisions are merely exceptions to the general rules derived from the French Code Civil.

DAvid F. Forte is Associate Professor of Law, Cleveland-Marshall College of Law. I am grateful for suggestions offered by Professor Leonard Jaffee, University of Louisville School of Law; Professor Sidney Jacoby, Cleveland-Marshall College of Law; and Professor Donna Divine, Department of Political Science, Smith College. 
This has placed devotees of the Sharī $a$ in a dilemma. Many Muslims maintain that if a modern code must be adopted, it must be done without any reference to the Sharï $a$, lest the divinity of Islamic legal norms be cast into doubt. These Muslim legal experts prefer to leave the Shari $a$ uncompromised as a source of law. To them, the incorporation of certain Islamic principles into a modern legal code in no way "legitimizes" such a code. To the contrary, they consider that the inclusion of Islamic principles in a code causes the Shari' $a$ to be made dependent and secondary.

The traditional legal norms are defended because they are considered to be of divine origin. Consequently, the authoritativeness of the Civil Code is constantly being challenged. Calls for a return to fundamental Islamic principles are an inescapable part of Egyptian life. ${ }^{1}$ The inclusion in a draft of a new penal code of a provision making apostasy a capital offense is a recent example. In addition, fundamentalist Muslims pose a political challenge to the government, for they seek to displace the legal authority on which the government is based. One of the movements which the Sadat government combats most fiercely is a fundamentalist movement which seeks a return to a society based upon "pure" Islamic values. Violence and repression are the hallmarks of the battle between this group and the government. ${ }^{2}$

Even if the Civil Code were accepted as authoritative by the Egyptian populace, problems would arise in its application. This is because many of the land law provisions of the Code are archaic. The Code's land law provisions were derived from like provisions of the French Civil Code, which in turn were based on Roman Law and traditional French practice extant at the end of the 18 th century. For example, the provision that a sale is not finalized until it is registered, but that once it has been registered all rights then accrue from the moment of sale (Art. 934), ${ }^{3}$ has led to much controversy. It causes many more disputes than would a simpler transfer law.

The final and most persuasive cause of the Code's lack of success in reforming land law is the destabilizing influence of the state. Throughout Egyptian history, the state has sought to exercise significant control over the ownership and use of land. From the earliest days of Islam, property was distinguished according to its tax status vis-à-vis the state. Under the Mamluks, lands were seized by the state, and then leased under a lease which gave the lessee what was tantamount to a freehold interest. Similarly, in the 19th century, Mohammed Ali appro-

1. Even Anwar Sadat publicly acknowledged this sentiment by stating, "Egypt should return to the main principles of our Muslim heritage." Critchfield, Egypt's Fellahin 1, Northeast Africa Series, July 1976.

2. 1976 Arab Report and Record 688; Sunday Times (London), 1 June 1975 at 1.

3. For the French version, see 1 Planiol, Treatise on the Civil Law, Pt. 2, No. 2615 (12th ed. 1969). 
priated most land to the state's use, and then returned it to private hands. Consequently, no matter how stable land holding relationships may be-whether under traditional Islamic law or a "modern" codethe possibility of state intervention in land ownership, for whatever political or ideological motives may move those in power, is ever present.

These three impediments to the successful operation of a modern civil code-traditional Islamic influences, archaic code provisions, and state interventionism-have plagued Egyptian law land throughout the Nasser and Sadat administrations. The unpredictability of state action has been the most persistent problem.

Scarcely three years after the promulgation of the Code, the Nasser regime, in pursuit of its policy of Arab socialism, began imposing restrictions on the ownership of land. The Land Reform Law of 1952 limited to 200 feddans the amount of land which an individual could own. Under that law, any land owned in excess of 200 feddans was taken by the state, paid for with long-term bonds, and distributed (in lots of from two to five feddans) to the fellahin, landless peasants. ${ }^{4}$ In 1961 , the maximum amount of land which an individual could own was reduced to 100 feddans. In 1963 , land owned by foreigners was expropriated. Finally, in 1969 , the maximum land holding was again reduced, this time to 50 feddans. ${ }^{5}$

As the land ownership ceiling was reduced, compensation for expropriated land diminished. In 1953, land holdings of the royal family and of officials of the monarchy were taken without compensation. Private holdings were also expropriated without compensation for a period. In 1964, the government cancelled all interest payments due on bonds given in exchange for expropriated lands, and declared that the bonds themselves were not redeemable. ${ }^{6}$

During the 1960's, arbitrary executive action taken for political motives became commonplace. At one time, Nasser ordered that confiscated lands be given to the veterans of the disastrous Yemeni war, an action which paralleled early Islamic practice. Simultaneously, he ordered the sequestration of the properties of political opponents. Under sequestration, the bare title of the property remains with the owner, while the state acquires the rights of alienation and use of the property, as well as the right to income derived from it. Thus, sequestration does not require compensation. ${ }^{7}$ There were two periods during which se(1962).

4. Gadalla, Land Reform in Relation to Social Development Egypt 38-39

5. Mabro, The Egyptian Economy 1952-72 at 63-64 (1972); Ministry of Agrarian Reform and Land Reclamation, Agrarian Reform and Land Reclamation 1952-63 at 29 (1963).

6. Mabro, supra n. 5 at 64 .

7. In the 19th century, sequestration was used as a penalty for non-payment of taxes. Mayfield, Rural Politics in Nasser's Egypt 31 (1963). 
questration was common: one was after the dissolution of the confederation with Syria, and the other was after the disastrous Seven-Day War with Israel in 1967. In all, approximately 15,000 persons had property sequestered during those two periods. ${ }^{8}$

No civil code can be considered as a legitimate and predictable source of law in the face of such executive capriciousness. In 1969 , Nasser turned against the judiciary. In his fear of political competition, fostered by Egypt's defeat at the hands of Israel in 1967, he believed that the courts harbored enemies to his regime. Although Egyptian law provided for removal of judges only by judicial procedure, Nasser reorganized the judiciary so that 100 judges were unseated. ${ }^{9}$

Almost immediately upon taking power, President Sadat evinced a desire to establish predictable legal procedure as part of a design to encourage economic development. He reinstated the judges whom Nasser had removed from office. He promised profit repatriation and guaranteed both foreign and domestic investors that their properties would not be expropriated. Attracting back domestic capital which was invested abroad during the Nasser years has proven to be a difficult task. $^{10}$ Following an order issued-but never executed-by Nasser, Sadat restored the properties confiscated from 19 former officials of the monarchy. ${ }^{11}$ Sadat has also given $\$ 10$ million in compensation to Americans whose holdings were confiscated by Nasser in 1961 .

Early attempts to rectify the excesses of sequestration were stymied for a while. In late 1970, Sadat decreed the return of sequestered lands, and in April of 1972 a Parliamentary committee recommended the payment of compensation to persons whose lands had been sequestered. However, nothing was done to effectuate the policy of rectifying the excesses of sequestration until 1974, when the Council of State, Egypt's highest court, declared Nasser's sequestration decrees illegal and ordered the return of sequestered properties. ${ }^{12}$ Following the decision of the Council of State, two methods of settlement were put into effect. Under one method, an arbitrary ceiling on financial settlements- $\$ 50,000$ per individual and $\$ 100,000$ per family-was imposed. Compensation for about $20 \%$ of all sequestered lands has been awarded under this method. Under the other method, full property rights can be returned to the bare owner, but the owner has to dispose of all property in excess of the 50 feddan (100 feddan per family) limit within one year after restoration of his property rights. Four hundred property owners have temporarily regained 10,000 feddans in this fashion. It is not clear

8. 1974 Arab Report and Record 79.

9. 1971 Arab Report and Record 563.

10. 1976 Arab Report and Record 476; 1975 A rab Report and Record 334; 1974 Arab Report and Record 169.

11. 1975 Arab Report and Record 306.

12. Apparently, the high value of the lands-reportedly worth $\$ 10$ billion-had caused Sadat to forestall making settlements. 
how much land remains subject to a right of settlement, for the traditional inefficiency of Egyptian bureaucracy has slowed the processing of claims. ${ }^{13}$

While attempting to undo the excesses of the Nasser regime, Sadat has not abandoned the policy of land reform fostered by his predecessor. The limitation of ownership of land to 50 feddans per individual remains. New lands are distributed to the fellahin, while ambitious plans for major reclamation projects have been announced ${ }^{14}$ Nevertheless, the success of the land reform policy is seriously threatened by natural impediments, a soaring birth rate, and legal chicanery. Higher water tables caused by the Aswan Dam have reduced agricultural production on lands surrounding the dam. The government recently admitted that the land reclamation programs had caused more losses in production than gains. Egypt's population of forty million is growing by $3 \%$ per year. ${ }^{15}$

Differentiation in landholding classes is once again occurring. Successful farmers are circumventing the limitation on land ownership: relatives are made titular owners of land to keep ownership within the letter of the law. These new entrepreneurs hire many peasants as day laborers and pay bribes to government officials to guarantee official "ignorance" of de facto violations of the law. In addition, money lenders are acquiring more land by foreclosing mortgages on farms. ${ }^{16}$

At the other end of the spectrum, many smaller holdings are being reduced to tiny plots. Although statute forbids the division of holdings of less than five feddans, many fellahin follow the traditional Islamic law of inheritance and divide their small farms among their children. ${ }^{17}$ Also, many small farmers forced to join government cooperatives have to engage in a form of sharecropping, which effectively reduces the size of their holdings in many instances.

There is pressure on the Sadat government to initiate further land reforms. Foreigners are still not allowed to own property worth more than 1,000 Egyptian pounds. This limitation has angered Arabs of other nationalities who have sought to purchase real property-particularly in urban areas-through Egyptian agents. ${ }^{18}$ There has long been agitation for an increase in maximum allowable landholdings. The government has "leaked" rumors that it will raise the maximum limit.

Egypt remains in severe economic straits. The government's efforts to encourage foreign and domestic investment have not yet achieved significant results. Much of the Sadat government's failure to build

13. 1974 Arab Report and Record 169.

14. 1975 Arab Report and Record 461, 584; 1976 Arab Report and Record 410.

15. Rubenstein, "Egypt Since the October War," 70 Current Hist. 14 (1976).

16. Critchfield, supra $n .1$ at 12-14.

17. Gadalla, supra n. 4 at 64-65.

18. The Times (London), 27 August 1976 at 1. 
confidence among investors is attributable to what is perceived to be a precarious hold on power by Sadat himself. Egypt's problems with Israel-and recently, with Libya-its demographic problems, and its archaic bureaucracy all contribute to its economic malady. However, even discounting these impediments, Egypt's attempt to modernize through the enactment of a Western-style civil code has not met with success. Traditional Islamic values, certain out-of-date code provișions, and the unpredictability of state action continue to vitiate the effectiveness of the Code. 